\title{
THE ROLE OF ACTH AND CORTISONE IN THE TREATMENT OF SYSTEMIC LUPUS ERYTHEMATOSUS
}

\author{
By J. N. Harris-Jones, M.D., M.R.C.P. \\ Senior Medical Régistrar, Royal Hospital, Sheffield
}

The steroids ACTH and cortisone have now been used in the treatment of systemic lupus erythematosus for over five years. Several reports on the results of treatment are available (Haserick, 1953; Dubois et al., 1952; Soffer and Bader, 1952; Harvey et al., 1954). There are few publications in the British literature in which the results of treatment are recorded. (Cohen and Cadman, 1953; Gold and Gowing, 1953; Richards, 1954.)

This report is an attempt to assess the results in a further 12 cases treated over the period, $195^{\circ}$ to 1954 .

The main clinical features of these 12 patients are recorded in Table $I$, and the main haematological features in Table 2. Differential plasma protein analysis showed an abnormal albuminglobulin ratio, at some stage of the disease, in eight cases (Fig 1). The clinical features and laboratory findings in this group permit little doubt that these patients were suffering from systemic lupus erythematosus.

Before attempting to assess the value of any therapeutic measure in this disease, the prognosis in the untreated case must be considered. Dubois et al. (1952) quote a mean expectation of life of 22 months, but Bundick and Ellis (I95I) record the figure of four and a half years. It is to be noted that in these groups the diagnosis in most cases lacked the confirmation of a positive L.E. cell test. This criticism does not apply to a series of ten patients seen by Haserick in the year 1948-49, all of whom showed a positive L.E. cell test. None received steroid therapy and at the time of his report in 1953 (Haserick, I953), one remained alive.

In the present series the patients have been under observation from $I$ to 58 months, following or during treatment. This group, therefore, provides material for an assessment of short term results in all cases, but an evaluation of the long term results of treatment is rather more limited.

\section{Treatment}

The dose and method of administration of ACTH and cortisone have varied in this series, but
TABLE I

Major Clinical Manifestations in 12 Cases of SYSTEMIC LuPUS ERYTHEMATOSUS

\begin{tabular}{|c|c|c|c|c|}
\hline \multirow{2}{*}{\multicolumn{2}{|c|}{$\begin{array}{l}\text { Symptom sign } \\
\ldots\end{array}$}} & & \multicolumn{2}{|c|}{ No. of cases } \\
\hline & & .. & .. & 10 \\
\hline Fever .. & .. & .. & .. & 12 \\
\hline Arthralgia: Arthritis & .. & .. & .. & 10 \\
\hline Pleurisy: Pneumonitis & .. & $\ldots$ & .. & II \\
\hline Pericarditis: Endocarditis & .. & .. & .. & 2 \\
\hline Cardiac failure $\quad \ldots$ & .. & .. & .. & \\
\hline teinuria $\quad \ldots \quad \ldots$ & .. & .. & .. & 10 \\
\hline tinitis: Cytoid bodies & . & .. & $\ldots$ & 3 \\
\hline C.N.S. involvement & .. & .. & .. & 4 \\
\hline Reynaud's phenomenon & .. & .. & & \\
\hline
\end{tabular}

are in accord with the generally accepted practice in this country.

Initial Therapy. This phase of treatment is considered to be that period from the start of treatment until a remission has been successfully induced, during which time high doses of ACTH or cortisone are usually employed. This period ranged from 18 days to 42 days in this group, with an average of 22 days.

Corticotrophin was used for the initial phase of therapy in eight patients. In seven instances it was given by the intramuscular route in doses ranging from $25 \mathrm{mg}$. to $200 \mathrm{mg}$. daily, and two patients received intravenous corticotrophin in doses of up to $50 \mathrm{mg}$. daily.

Cortisone, given orally in daily doses of $100 \mathrm{mg}$. to $300 \mathrm{mg}$., was used in three cases. One patient received both ACTH and cortisone (table 3).

Maintenance Therapy. Continuous steroid therapy was maintained in six cases. In two patients treatment was discontinued for a short period after the initial course, but was resumed because of a severe recrudescence of symptoms, and it is notable that in neither case was the second course effective. In the remaining four patients hormonal therapy was discontinued after the initial course either by design or because of complications.

Intramuscular ACTH gel was used for maintenance treatment in two cases, the dose varying from $15 \mathrm{mg}$. to $25 \mathrm{mg}$. daily. Oral cortisone, in amounts ranging from $50 \mathrm{mg}$. to $75 \mathrm{mg}$. daily, was given to four patients ('Table 3 ). 
TABLe 2

HaEmatology

\begin{tabular}{|c|c|c|c|c|c|c|c|}
\hline Case & Sex & Age & Hb (g.) & W.B.C. & E.S.R. & L.E. cells & Platelets \\
\hline I & F & 57 & 11.0 & $6, \infty 00$ & 32 & + & 220,000 \\
\hline 2 & F & 39 & 7.0 & 1,700 & 70 & + & Nil \\
\hline 3 & F & 30 & 8.4 & $1, \infty 00$ & 120 & + & 64,000 \\
\hline 4 & F & 39 & 6.36 & 3,000 & 140 & + & Normal \\
\hline 5 & F & 57 & 7.4 & 2,500 & $12 \mathrm{I}$ & + & Normal \\
\hline 6 & F & 23 & 9.2 & 4,000 & 50 & + & 110,000 \\
\hline 7 & $\mathbf{F}$ & 44 & 10.4 & 6,500 & 50 & + & - \\
\hline 8 & F & 14 & 13.0 & 3,400 & 62 & $\longrightarrow$ & $\longrightarrow$ \\
\hline 9 & F & 56 & II.4 & 5,000 & 50 & + & $\longrightarrow$ \\
\hline 10 & $\mathbf{M}$ & 22 & 9.5 & 4,000 & 63 & + & Normal \\
\hline I I & F & 34 & I I. 4 & 2,000 & 39 & + & Normal \\
\hline 12 & $\mathbf{F}$ & 50 & II.5 & 1,800 & $3 I$ & \pm & Normal \\
\hline
\end{tabular}

CPMS.

7

6

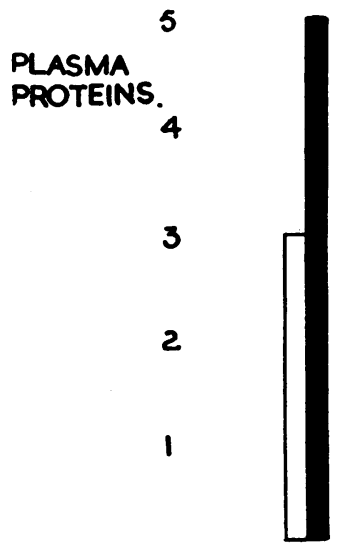

I
ALBUMIN.

GLOBULIN.

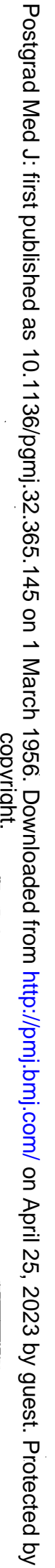


TABle 3

\begin{tabular}{|c|c|c|c|c|c|c|c|c|}
\hline \multirow{2}{*}{ Case } & \multirow{2}{*}{ Age } & \multirow{2}{*}{ Sex } & \multicolumn{4}{|c|}{ Treatment } & \multirow{2}{*}{ Results } & \multirow{2}{*}{$\begin{array}{c}\text { Period } \\
\text { (Months from start } \\
\text { of treatment) }\end{array}$} \\
\hline & & & Initial & Mg./day & Maintenance & Mg./day & & \\
\hline $\mathbf{I}$ & 57 & F & ACTH & $25-30$ & None & 一 & Remission & 54 \\
\hline 2 & 39 & $\mathbf{F}$ & ACTH & $25-50$ & Cortisone* & $50-150$ & Died & 5 \\
\hline 3 & 30 & F & Cortisone & $100-300$ & None & - & Died & 27 \\
\hline 4 & 39 & F & Cortisone & 100 & Cortisone & $50-75$ & Died & $2 \mathrm{I}$ \\
\hline 5 & 57 & $\mathbf{F}$ & Cortisone & $100-150$ & Cortisone & 50 & Died & 5 \\
\hline 6 & 23 & $\mathbf{F}$ & ACTH & 50 & ACTH* & $50-200$ & Died & 7 \\
\hline 7 & 44 & $\mathbf{F}$ & ACTH. & $50-100$ & Cortisone & 75 & Died & 8 \\
\hline 8 & 14 & F & АС́TH & 200 & None & - & Remission & 30 \\
\hline 9 & 56 & F & $\left.\begin{array}{l}\text { ACTH } \\
\text { Cortisone }\end{array}\right\}$ & $100-200$ & Cortisone & 100 & Remission & $\mathbf{I}$ \\
\hline 10 & 22 & $\mathbf{M}$ & ACTH & 40 & ACTH & 15 & Relapse & 3 \\
\hline II & 34 & F & ACTH & $50-100$ & АCTH & 25 & Relapse & 30 \\
\hline 12 & 50 & $\mathbf{F}$ & ACTH & $50-75$ & None & 一 & Relapse & 26 \\
\hline
\end{tabular}

*In cases 2 and 6 this represents a second ' initial' course

TABLE 4

Results of Treatment-ACTH and Cortisone

\begin{tabular}{|c|c|c|c|c|c|c|c|c|}
\hline \multirow{2}{*}{ Case } & \multirow{2}{*}{ Sex } & \multirow{2}{*}{ Age } & \multicolumn{2}{|c|}{ W.B.C. } & \multicolumn{2}{|c|}{ E.S.R. } & \multicolumn{2}{|c|}{ L.E. cells } \\
\hline & & & Before & After & Before & After & Before & After \\
\hline $\mathbf{I}$ & $\mathbf{F}$ & 57 & $7, \infty 00$ & 5,000 & 39 & 44 & + & + \\
\hline 2 & $\mathbf{F}$ & 39 & 4,500 & 5,100 & 73 & 56 & + & - \\
\hline 3 & $\mathbf{F}$ & 30 & 1,000 & 1,900 & IOI & 102 & + & + \\
\hline 4 & $\mathbf{F}$ & 39 & $3, \infty 00$ & 5,000 & 100 & 123 & + & + \\
\hline 5 & $\mathbf{F}$ & 57 & 4,000 & 4,000 & 127 & 121 & + & + \\
\hline 6 & $\mathbf{F}$ & 23 & 8,000 & 4,000 & 40 & 62 & + & + \\
\hline 7 & $\mathbf{F}$ & 44 & 6,500 & $8, \infty 00$ & 14 & 50 & + & + \\
\hline 8 & $\mathbf{F}$ & 14 & 4,000 & $1, \infty 00$ & 59 & $5 I$ & - & - \\
\hline 9 & $\mathbf{F}$ & 56 & 5,000 & 8,000 & 50 & 23 & + & + \\
\hline 10 & $\mathbf{M}$ & 22 & 4,000 & 4,900 & 62 & 62 & Negative & + \\
\hline II & $\mathbf{F}$ & 34 & 3,000 & 6,000 & 63 & $6 r$ & + & + \\
\hline 12 & $\mathbf{F}$ & 50 & 1,800 & $\longrightarrow$ & $3 I$ & 45 & + & + \\
\hline
\end{tabular}




\section{Results}

The efficacy of these hormones in the treatment of systemic lupus erythematosus may best be judged by their effect on the two phases of the disease, namely, the acute state, or 'lupus crises,' and the subacute phase.

It is now well documented that they frequently exert a dramatic effect on the acute stage, and may appear life saving (Cary et al., 1950; Soffer et al., 1950; Haserick et al., 195I; and Dubois et al., 1952; Harvey et al., 1954). In this series fever was controlled, at least initially, in all except one case, usually within the first 48 hours. In six patients fever recurred within the first ten days of treatment. Disseminated skin lesions present in nine patients cleared within about ten days of the start of treatment. Patients with arthritis or arthralgia claimed relief as a result of treatment, and there was often an objective reduction in periarticular swelling. For two reasons it is difficult to assess the effect of ACTH or cortisone on the pleuro-pulmonary lesions. Firstly, it is not easy to distinguish, clinically or radiologically, between a secondary infective process, and the 'specific' pulmonary lesions described by Rakov and Taylor (1942) and Thorell (1952). Secondly, the almost invariable use of antibiotics in this group makes any evaluation of steroid therapy unreliable. In this series, four patients developed extensive pulmonary changes only after treatment had commenced. As noted by Ragan (1952) two patients with significant renal involvement responded poorly to steroid therapy, and in only one case in the group was there an appreciable reduction in albuminuria following treatment.

In Table 4, details of the total white count, E.S.R., and L.E. cell tests immediately before, and after four to six weeks' treatment are presented. It will be seen that of the seven cases with a leukopaenia immediately before the start of treatment, four showed an increase in total white count; the small numbers involved and the known spontaneous variation in white cell counts in this disease make this an observation of doubtful significance. In only one case was the sedimentation rate reduced during treatment, and in many the rate actually increased, a feature noted previously by Thorn et al. (1950) and Dubois et al. (1952). The L.E. cell phenomenon persisted throughout this period of observation in eight patients, although fading in intensity towards the end of the period.

Table 5 records the plasma protein analysis immediately before, and after four to six weeks' treatment, and it is apparent that there is no tendency for the abnormal protein pattern to return to normal within this period. In fact in
TABLE 5

Results of Treatment-ACTH and Cortiso Plasma Proteins

\begin{tabular}{|c|c|c|c|c|c|c|c|}
\hline Case & Sex & Age & & efor & & & After \\
\hline I & $\mathbf{F}$ & 59 & & $\begin{array}{l}= \\
=\end{array}$ & $\begin{array}{l}3.8 \\
2.7\end{array}$ & $\begin{array}{l}\mathbf{A} \\
\mathbf{G}\end{array}$ & 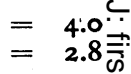 \\
\hline 2 & $\mathbf{F}$ & 39 & $\begin{array}{c}\mathbf{A} \\
\mathbf{G}\end{array}$ & $\begin{array}{l}= \\
=\end{array}$ & $\begin{array}{l}2.3 \\
4.3\end{array}$ & $\begin{array}{l}\mathbf{A} \\
\mathbf{G}\end{array}$ & $\begin{array}{l}=2.9 \text { 을 } \\
=4.2 \text { 을 }\end{array}$ \\
\hline 3 & F & 30 & $\begin{array}{c}\mathbf{A} \\
\mathbf{G}\end{array}$ & $\begin{array}{l}= \\
=\end{array}$ & $\begin{array}{l}4.0 \\
2.7\end{array}$ & $\begin{array}{l}\mathbf{A} \\
\mathbf{G}\end{array}$ & $\begin{array}{l}=2.9 \overrightarrow{\mathbb{\Phi}} \\
=4.2\end{array}$ \\
\hline 4 & $F$ & 39 & $\begin{array}{l}\mathrm{A} \\
\mathbf{G}\end{array}$ & $\begin{array}{l}= \\
=\end{array}$ & $\begin{array}{l}3.4 \\
5.0\end{array}$ & $\begin{array}{l}\mathbf{A} \\
\mathbf{G}\end{array}$ & $\begin{array}{l}=2.4 \\
=4.7\end{array}$ \\
\hline 5 & $\mathbf{F}$ & 57 & $\begin{array}{l}\mathbf{A} \\
\mathbf{G} .\end{array}$ & $\begin{array}{l}= \\
=\end{array}$ & $\begin{array}{l}3.2 \\
1.9\end{array}$ & $\begin{array}{l}\mathbf{A} \\
\mathbf{G}\end{array}$ & $\begin{array}{l}=3.2 \vec{\omega} \\
=2.0 \mathrm{~g}\end{array}$ \\
\hline 6 & $F$ & 23 & $\begin{array}{l}\mathbf{A} \\
\mathbf{G}\end{array}$ & $\begin{array}{l}= \\
=\end{array}$ & $\begin{array}{l}3.3 \\
3.8\end{array}$ & $\begin{array}{l}\mathbf{A} \\
\mathbf{G}\end{array}$ & $\begin{array}{l}=3.23 \\
=3.8 \omega\end{array}$ \\
\hline 7 & F & 44 & $\begin{array}{l}\mathbf{A} \\
\mathbf{G}\end{array}$ & $\begin{array}{l}= \\
=\end{array}$ & $\begin{array}{l}3.9 \\
1.9\end{array}$ & $\begin{array}{l}\mathbf{A} \\
\mathbf{G}\end{array}$ & $\begin{array}{l}=5.2 \omega \\
=1.7 \%\end{array}$ \\
\hline 8 & F & 14 & $\begin{array}{l}\mathbf{A} \\
\mathbf{G}\end{array}$ & $\begin{array}{l}= \\
=\end{array}$ & & $\stackrel{A}{\mathbf{G}}$ & $\begin{array}{l}= \\
=\end{array}$ \\
\hline 9 & F & 56 & $\begin{array}{l}\mathbf{A} \\
\mathbf{G}\end{array}$ & $\begin{array}{l}= \\
=\end{array}$ & $\begin{array}{l}3.2 \\
2.7\end{array}$ & $\stackrel{A}{G}$ & $\begin{array}{l}= \\
=\end{array}$ \\
\hline IO & $\mathbf{M}$ & 22 & $\begin{array}{l}\mathbf{A} \\
\mathbf{G}\end{array}$ & $\begin{array}{l}= \\
=\end{array}$ & $\begin{array}{l}2.4 \\
2.0\end{array}$ & $\stackrel{\mathbf{A}}{\mathbf{G}}$ & $\begin{array}{l}=2.8 \mathrm{~S} \\
=2.9 \overrightarrow{0}\end{array}$ \\
\hline II & F & 34 & $\begin{array}{l}\mathbf{A} \\
\mathbf{G}\end{array}$ & $\begin{array}{l}= \\
=\end{array}$ & $\begin{array}{l}2.8 \\
2.5\end{array}$ & $\stackrel{\mathbf{A}}{\mathbf{G}}$ & $\begin{array}{l}=32 . \\
=30\end{array}$ \\
\hline 12 & F & 44 & $\begin{array}{l}\mathbf{A} \\
\mathbf{G}\end{array}$ & $\begin{array}{l}= \\
=\end{array}$ & $\begin{array}{l}2.0 \\
6.7\end{array}$ & $\begin{array}{l}A \\
G\end{array}$ & $\begin{array}{l}\overrightarrow{\mathrm{i}} .5 \leq 5 \\
2.6 \overline{\mathrm{O}}\end{array}$ \\
\hline
\end{tabular}

only one case did the high globulin level fåt, whereas in three cases there was an increase in the globulin level together with a reversal of the A $\$$ ratio after treatment. This is not in agreement with the observations of Soffer and Bader (195年) or of Cohen and Cadman (1953) but these authers do not state their period of observation. It 3 s possible that a more detailed analysis of the globulin sub-fractions would have shown different trend.

As already stated, this group does not allow of long term study, but it should be noted that of the 12 cases treated with ACTH and cortisone sinee 1950, half have died. The average duration of 1 ife after commencement of treatment in the six who have succumbed was 12 months. The impression gained from the close follow-up of five patients on long-term maintenance therapy has been that these steroids merely modify and subdue the inevitake progress of the disease. At no time after the stort of treatment was there enough evidence to suggerst that the pathological changes characteristic of systemic lupus erythematosus had been arrested. Of the six patients who remain, three were 
hospital in relapse at the time of this report. Three patients are in remission, two of whom no longer receive maintenance treatment.

Side effects produced by corticotrophin and cortisone have been prominent in this group. Familiar complications such as hypertension with fits, hypokalaemia, steroid diabetes, and acute mania have been encountered. Two patients have developed miliary tuberculosis during the course of treatment, and in neither case was a tuberculous focus suspected before the commencement of treatment; this potential hazard has been recorded previously (Harris-Jones and Pein, I952; Walker, 1952).

\section{Discussion}

This group of patients has been studied and presented because the results of treatment differ from some previously reported (Cohen and Cadman, 1953; Rishards, 1954). In their study of a group comparable to the present one, Soffer and Bader (1952) quote a mortality of 33 per cent. In a recent survey of 62 cases treated with ACTH and cortisone, Harvey et al. (1954) record a mortality of 29 per cent.; in 26 per cent. the disease appeared inactive following a single course of steroid therapy; 18 per cent. required continuous maintenance therapy.

The impression gained from the present study, is that although these hormones may induce a remission, particularly in the acute phase, they have little influence on the subsequent course of the disease. Their effect on the pulmonary lesions is unpredictable, and in this respect their use may be hazardous. The thrombocytopaenic state appears uninfluenced by treatment. When the haematological and biochemical results of treatment are set against the clinical response, it seems difficult to conceive that the fundamental pathological process is being arrested. It appears more likely that ACTH and cortisone merely modify the hyper-immune state, and minimize the antigen-antibody reactions presumably responsible for the disease process. Despite their obvious limitations however, these steroids remain the most valuable weapons yet available for the treatment of systemic lupus erythematosus.

\section{Summary}

The results of the treatment of 12 cases of systemic lupus erythematosus with ACTH and cortisone are recorded. An evaluation of these results has been attempted, and from this it has been concluded that although these steroids modify the acute phase of the disease, there is less evidence that they influence its subsequent course.

It is a pleasure to record my gratitude for the great help and encouragement I have received from the physicians and dermatologists of the Royal Hospital, and Royal Infirmary, Sheffield, under whose care the patients were admitted. I would also like to express my thanks to Professor C. H. Stuart-Harris for his helpful criticisms of this paper.

\section{BIBLIOGRAPHY}

BUNDICK, W. R., and ELLIS, F. A. (195I), Sth med. F. Bgham, Ala., 44, 404.

CAREY, R. A., HARVEY, A. M., and HOWARD, J. E. (1950), Bull. Fohns Hopkins Hosp., 87, 425.

COHEN, SIR HENRY, and CADMAN, E. F. B. (1953), Lancet, ii, 305 .

DUBOIS, E. L., COMMONS, R. R., STARR, P., STEIN, C. S., and MORRISON, R. (1952), F. Amer. med. Ass., 149, 995.

GOLD, S. C., and GOWING, N. F. C. (1953), Quart. f. Med., 22, 457.

HARRIS-JONES, J. N., and PEIN, N. K. (1952), Lancet, ii, 115. HARVEY, A. M., SHULMAN, L. E., TUMULTY, P. A., CONLEY, C. L., and SHONERICH, E. H. (1954), Medicine, Baltimore, 33, 291.

HASERICK, J. R., CORCORAN, A. C., and DUSTAN, H. (195 I), Э. Amer. med. Ass., 146, 643 .

HASERICK, J. R. (1953), Arch. Derm., 68, 714.

RAKOV, H. L., and TAYLOR, J. S. (1942), Arch. int. Med., 70, 88.

RICHARDS, D. G. (1954), Brit. med. F., ii, 777.

SOFFER, L. J., LEVITT, M. F., and BAEHR, G. (1950), Arch. int. Med., 86, 558.

SOFFER, L. J., and BADER, R. (1952), F. Amer. med. Ass., 149, IOO2.

THORELL, I. (1952), Acta. Radiol., 37, 8.

THORN, G. W., BAYLES, T. B., MASSELL, B. F., FORSHAM, P. H., HILL, S. R., SMITH, S., and WARREN, J. E. (1949), New Eng. F. Med., 241, 529.

WALKER, B. (1952), Proc. Roy. Soc. Med., 45, 167.

\title{
Index for 1955 is now ready. Have your Journals
}

\section{bound up into a volume NOW. See advertise-}

\author{
ment on page 172 for details.
}

